\title{
Changes in nesting sites abundance and their use by woodpeckers along an urban gradient: a ten-year comparison
}

\author{
Francesca Protti-Sánchez ${ }^{1 *} \&$ Luis Sandoval ${ }^{2}$ \\ 1. Posgrado en Biología, Sistema de Estudios de Posgrado, Universidad de Costa Rica, Montes de Oca, San José, Costa \\ Rica; fprottis@gmail.com \\ 2. Escuela de Biología, Universidad de Costa Rica, Montes de Oca, San José, Costa Rica; biosandoval@gmail.com \\ * Correspondence
}

\author{
Received 18-VIII-2017. Corrected 18-XII-2018. Accepted 17-I-2019.
}

\begin{abstract}
Woodpeckers nesting substrate abundance may be reduced by urban expansion, negatively affecting their reproduction. Long-term studies in the tropics are rare but valuable to estimate how urban development has affected ecological communities. We present a ten-year comparison on nesting substrate abundance and their use by Melanerpes rubricapillus and M. chrysauchen woodpeckers along an urban gradient in Golfito, Costa Rica; which include three habitats and three substrates (snags, palms, and posts). Conditions remained unchanged in non-urban areas. In semi-urban areas, snag, posts, and nests on them, have decreased. In urban areas, despite snags and posts remaining constant, their use also decreased. In semi-urban and urban areas, palms and palm nests increased. This long term comparison indicates that woodpeckers took advantage of the increased presence of ornamental palms in gardens.
\end{abstract}

Key words: Costa Rica; Golfito; Melanerpes chrysauchen; Melanerpes rubricapillus; nests; snags.

Protti-Sánchez, F., \& Sandoval, L. (2019). Changes in nesting sites abundance and their use by woodpeckers along an urban gradient: a ten-year comparison. Revista de Biología Tropical, 67(2) Suplemento, S274-S281.

Woodpeckers excavate cavities for nesting and roosting in snags, dead parts of living trees, and artificial substrates such as phone posts (Peterson \& Grubb, 1983; Stiles \& Skutch, 1989; Sandoval, 2009). These substrates are a very important resource not just for woodpeckers, but also for other birds that use old woodpecker nests (secondary cavity nesters) or natural cavities for nesting and roosting (Gibbs, Hunter, \& Melvin, 1993; Sandoval \& Barrantes, 2009; Cockle, Bodrati, Lammertink, \& Martin, 2015). Tropical habitats have lower densities of snags when compared to temperate habitats (Gibbs et al., 1993; Sandoval \& Barrantes, 2006; Cornelius et al., 2008) because warmer weather conditions increase the decomposition rate; hence, snags have less standing time (Gibbs et al., 1993; Sandoval \& Barrantes, 2009). As a result, nesting substrates are a limited resource, and may be the most important resource for woodpeckers' reproduction in both urban and rural habitats, since resources such as food can be obtained from nearby natural areas (Cornelius et al., 2008; Sandoval \& Barrantes, 2009).

In the South Pacific area of Costa Rica it is possible to find two species of woodpeckers: Melanerpes rubricapillus (Cabanis, 1862) and M. chrysauchen (Salvin, 1870). Both woodpecker species' nesting season goes from January to June (Stiles \& Skutch, 1989; Sandoval, 2009), and their main nesting substrates are 
snags, dead parts of live trees, and anthropogenic substrates such as utility poles (Stiles \& Skutch, 1989; Sandoval, 2009). Melanerpes rubricapillus is common in open areas of the forest, as well as in gallery woodlands, mangroves, secondary growth, and open areas with few trees and gardens (Stiles \& Skutch, 1989; Garrigues \& Dean, 2014). On the other hand, M. chrysauchen inhabits the canopy and middle levels of wet forests, but due to the reduction of these areas, they have extended more towards open areas and scattered trees (Stiles \& Skutch, 1989).

The South Pacific area of Costa Rica has suffered high levels of forest reduction due to population growth (Rosero-Bixby, MaldonadoUlloa, \& Bonilla-Carrión, 2002) and the lack of laws regulating wood extraction (Barrantes \& Lobo, 2005). As a consequence of this deforestation and the short time of snags' availability in the area (Sandoval \& Barrantes, 2009), the density of this necessary resource for woodpecker reproduction may be reduced (Gibbs et al., 1993; Cornelius et al., 2008). In order to understand the abundance of resources used by cavity nesting birds and its population dynamics in tropical forests, especially in managed and urban habitats, it is necessary to conduct long-term studies and comparisons (Gibbs et al., 1993; Cornelius et al., 2008; Magurran et al., 2010; Cockle et al., 2015).

Therefore, our main goal was to compare how the abundance of nesting substrates and the use in M. rubricapillus and M. chrysauchen changed over a ten-year period along an urban gradient. In order to assess this; we compared data obtained in 2005 by Sandoval (2009) and in 2015 along an urban gradient in the South Pacific of Costa Rica. We expect that over time, there has been a change on substrate availability and use by woodpeckers due mainly to urban development, since large human development lowers the abundance and diversity of nesting substrates (Cornelius et al., 2008; Sandoval, 2009). Furthermore, non-suitable nesting substrates may be available in urban areas, though this could contribute to a decrease in woodpecker populations in these areas.

\section{MATERIALS AND METHODS}

Study Area: We collected the data along an urban gradient in Golfito, Puntarenas province, Costa Rica $\left(8^{\circ} 37^{\prime}-8^{\circ} 40^{\prime} \mathrm{N}, 83^{\circ} 9^{\prime}-8^{\circ} 12^{\prime}\right.$ $\mathrm{W})$, between 5 and $190 \mathrm{~m}$ above sea level (Fig. 1). The studied area is a tropical wet forest with an average annual precipitation ranging from 3000 to $5000 \mathrm{~mm}$ (Lobo \& Bolaños, 2005; Sandoval, 2009).

Sampling: Samples were obtained between the $17^{\text {th }}$ and $27^{\text {th }}$ of January 2005 (Sandoval, 2009) and between the $13^{\text {th }}$ and $15^{\text {th }}$ of January 2015 because is the beginning of the nesting season of both woodpeckers species (Stiles \& Skutch, 1989). In both sample periods, we visited the same three zones (Fig. 1) from 08:00 to 12:00 hr. The three zones show the same degree of urbanization observed in 2005 (pers. obs.); therefore, each zone was marked off and classified in terms of urban development and vegetal coverage based on GIS. We assessed the coverage based on the land use, estimated using Google Earth professional's polygon function. Each area is described as follows: non-urban area: is allocated on the edge of Golfito Wildlife Refuge, human structures are absent or very limited, has gravel roads with low vehicular traffic volume, and has the highest vegetal coverage (dominated by natural mature secondary forest and forest edges) and comprises a total of 25 ha. Semi-urban area: human structures cover 30 to $74 \%$ of the available area, mixed with gardens that included isolate trees or palms and young secondary forest edges; roads are a mix of gravel and pavement with low to moderate vehicular traffic volume; it comprises a total area of 65.68 ha. Urban area: human buildings cover more than the $75 \%$ of available area, with small or absent gardens, and some isolate ornamental trees on the sidewalk, all roads are pavement and have high and continuous traffic volume, and comprises a total of 25.5 ha.

We sampled each area walking at a moderate speed along the roads (gravel and pavement; Fig. 1) looking for substrates which 


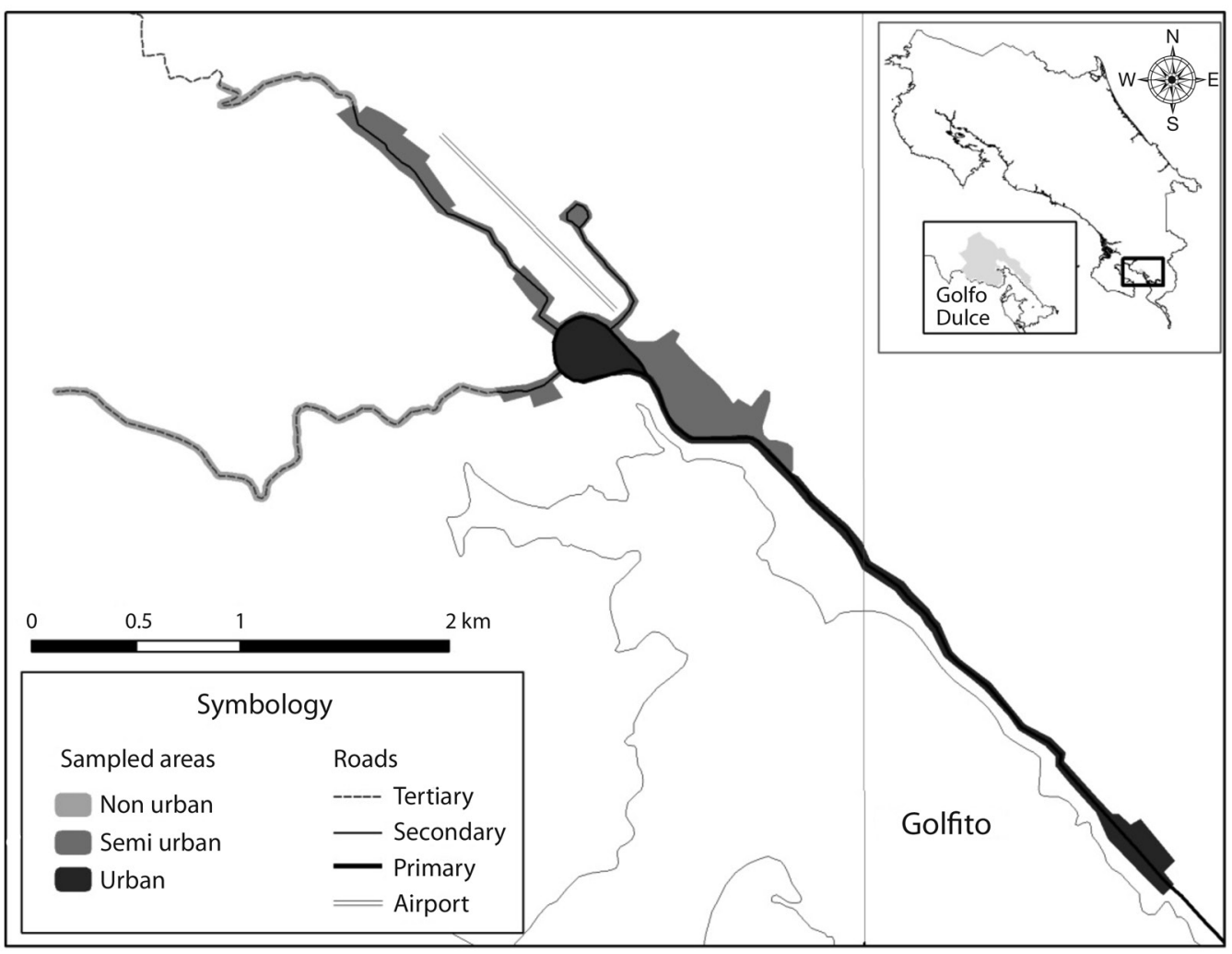

$83^{\circ} 10^{\prime} 0^{\prime \prime} \mathrm{W}$

Fig. 1. Study area showing the trails used in the three sampled areas during 2005 and 2015 to measure the abundance of substrates used and not used by two woodpecker species (Melanerpes rubricapillus and M. chrysauchen). At the right upper corner the Costa Rica map indicating the location of study area in the country.

could be used by $M$. rubricapillus and $M$. chrysauchen for nesting; whenever we found a suitable substrate we stopped and checked for cavities. All sidewalks, road edges (from the edge to $10 \mathrm{~m}$ inside the natural vegetation), house gardens, and empty lots which allowed access were covered and they are an accurate representation of the sampled area.

For a substrate to be considered suitable for nesting, as in 2005 (Sandoval, 2009), it needs to have the following three characteristics: (1) if it is a dead part in a live tree, it must have a diameter $\geq 10 \mathrm{~cm}$, but if it is a snag or utility pole it must have a diameter at breast height $\geq$ $10 \mathrm{~cm}$. Since there is no data available about the minimum diameter in which viable nests from $M$. rubricapillus and $M$. chrysauchen can be built, we used data from M. hoffmannii, a closely related and similar in size to the study species as a reference (Sandoval \& Barrantes, 2006; Sandoval, 2008). (2) A canopy coverage with values between 0 and 2 according to Remsen \& Robinson (1990) and Sandoval \& Barrantes (2006) scale, which corresponds to canopy coverage between 0 and $40 \%$ as proper for both woodpecker species establishing their nest. (3) No vegetation (e.g., epiphytes, bromeliads, and mosses) on at least some portion of the substrate to allow the host to create a cavity (Rico \& Sandoval, 2014). We classify each substrate in the follow three categories: snags and dead parts of live trees (hereafter snags), dead palm trees (palms), and wood utility poles (phone posts).

To consider that a substrate had at least one cavity made by our target species (i.e, it was used by one of the two Melanerpes species) and avoid an overestimation by including 
cavities built by other species (e.g., parrots or other woodpeckers), the cavity needs to show a circular entrance with a diameter from 5 to $7 \mathrm{~cm}$. This characteristic is similar to cavity entrances of $M$. hoffmannii nests (Sandoval, 2008), a woodpecker species similar in size of the two studied here and for which the data is available (in contrast with the studied species where this data is lacking). Additionally, although other woodpecker species are present in the study area (e.g., Dryocopus lineatus and Campephilus guatemalensis), those species build cavity nests with larger entrances and a square form (Rico \& Sandoval, 2014), making the differentiation between both groups of woodpecker species easy. We only counted as a nest cavity those that showed the right diameter and form in the entrance, and extending into the substrate with the back wall being non-visible from multiple angles on ground using binoculars (8x42 and 10x42).

We analyzed the data from both woodpecker species together because the majority of cavities were empty and it was not possible to establish which species built the nest, given that both species make a cavity entrance with the same characteristics (Sandoval, 2009). Also, $M$. chrysauchen and M. rubricapillus had been reported to build their nest in the same snag (Short, 1979), and both species occurred in the three studied sites given that they inhabit forest edges, open areas with trees and thicker secondary growths (Stiles \& Skutch, 1989; Gorman, 2014). Additionally, we observed that the abundance of both species was similar in the three sites. Accordingly we are not considering active use of the substrates but their availability and use over time by both woodpecker species.

Statistical Analyses: We used a chi-square test of independence to compare if the abundance of substrates (all together) changed per urban development area between 2005 and 2015. We used another chi-square test to compare if the abundance and use (at least one cavity present in the substrate) of substrate type per area (non-urban, semi-urban, and urban) changed between 2005 and 2015.

\section{RESULTS}

A total of 250 nests were found in 2005, compared to 343 in 2015, and the densities of potential and used substrates decreased in nonurban and semi-urban areas, but increased in urban areas from 2005 to 2015 (Table 1). Nests densities decreased in non-urban, but increased in semi-urban and urban areas (Table 1). When we compared the substrate abundance (without taking into account the type) within area (non-urban, semi-urban, and urban) per year, abundances were similar between 2005 and $2015\left(X^{2}=4.63\right.$, d.f. $=2, P=0.10$; Table 2$)$. The abundance of substrates per area changed differently. In the non-urban area, we found similar abundance of palms, snags, and posts between 2005 and $2015\left(\mathrm{X}^{2}=2.07\right.$, d.f. $=2, \mathrm{P}=$ 0.35 ; Fig. 2). In the semi-urban area, we found less palms, but more snags and posts in 2005 than in $2015\left(X^{2}=9.20\right.$, d.f. $=2, P=0.013$; Fig. 2). In the urban area, we found less palms, but

\section{TABLE 1}

Densities (quantity/ha) of potential and used substrates and nests of M. rubricapillus and M. chrysauchen along an urban gradient in 2005 and 2015 years

\begin{tabular}{lccc} 
& $\begin{array}{c}\text { Potential } \\
\text { substrates }\end{array}$ & $\begin{array}{c}\text { Used } \\
\text { substrates }\end{array}$ & Nests \\
2005 & & & \\
Non urban & 2.24 & 0.48 & 1.16 \\
Semi urban & 2.34 & 1.05 & 2.83 \\
Urban & 3.41 & 0.98 & 1.37 \\
2015 & & & \\
Non urban & 1.44 & 0.12 & 0.24 \\
Semi urban & 2.07 & 0.91 & 3.7 \\
Urban & 3.8 & 0.94 & 3.69 \\
\hline
\end{tabular}

TABLE 2

Abundance of substrates for nesting of Melanerpes rubricapillus and $M$. chrysauchen according to the area for both time periods, in Golfito, Costa Rica

\begin{tabular}{lcc} 
& \multicolumn{2}{c}{ Year } \\
\multicolumn{1}{c}{ Area } & 2005 & 2015 \\
Non-urban & 56 & 36 \\
Semi-urban & 154 & 136 \\
Urban & 87 & 97 \\
\hline
\end{tabular}



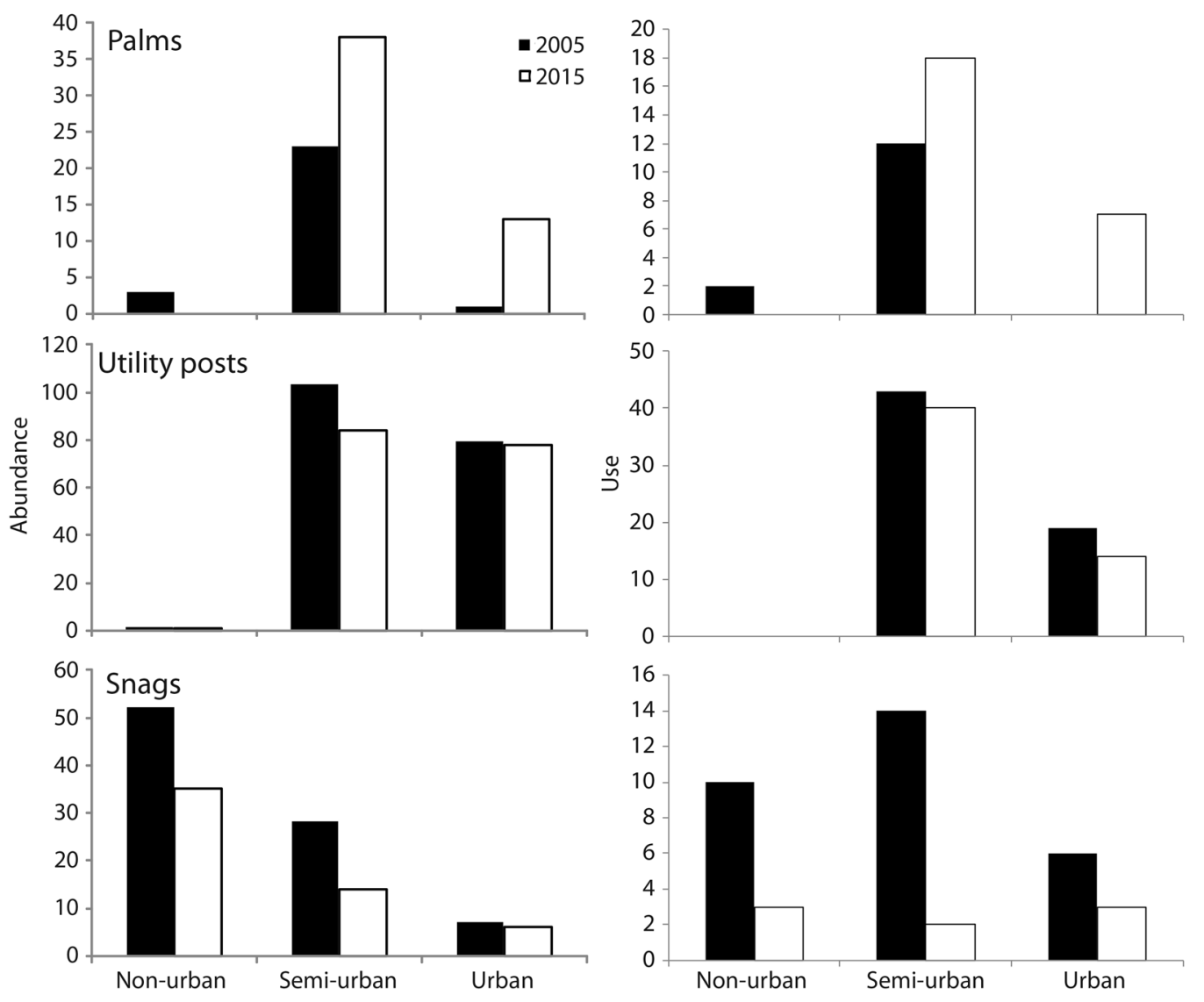

Fig. 2. Abundance of three substrate types and use for nesting by Melanerpes rubricapillus and M. chrysauchen in three areas with different degree of urbanization, for 2005 (black) and 2015 (white) in Golfito, Costa Rica.

the abundance of snags and posts was similar between 2005 and $2015\left(X^{2}=9.85\right.$, d.f. $=2, P$ $=0.007$; Fig. 2).

The proportion of substrates used per type by woodpeckers in non-urban areas was similar between 2005 and $2015\left(\mathrm{X}^{2}=0.58\right.$, d.f. $=1, \mathrm{P}$ $=0.44$; Fig. 2). The proportion of palms used as substrates increased, but the proportion of snags and posts used decreased in the semiurban $\left(X^{2}=9.72\right.$, d.f. $\left.=2, P=0.007\right)$ and urban area $\left(\mathrm{X}^{2}=8.74\right.$, d.f. $\left.=2, \mathrm{P}=0.01\right)$ between 2005 and 2015 (Fig. 2).

\section{DISCUSSION}

In this study, we performed a ten year comparison (2005 vs. 2015) on natural (dead palms and snags) and artificial substrate abundance for woodpecker nesting along an urban gradient, and we found that the abundance of nesting substrate types for woodpecker changed according to the degree of urban development over the ten year period comparison. In the non-urban area, substrate abundance for nesting was similar between 2005 and 2015 and there were no changes in the proportion of use by both woodpecker species, although we found a lower number of substrates used in 2015 . The lack of change in substrate abundance in this non-urban area may be the result of a low anthropogenic influence (e.g., remove snags and dead palms with the goal to avoid possible accidents; McClelland \& Frissell, 1975; DeLong, Fall, \& Sutherland, 2004; Blewett \& 
Marzluff, 2005) due this study area being a part of Golfito Wildlife Refuge (Lobo \& Bolaños, 2005). This result is in concordance with long term studies in temperate forests (Blewett \& Marzluff, 2005), where natural habitats that lack anthropogenic influence, show a similar abundance of nesting substrates over time.

The abundance of palm substrates in semiurban and urban areas increased over time, as well as their use by both woodpecker species. This may be the result of the increasing use of ornamental palms in house gardens and parks due to palms' faster growth rate than most ornamental trees (Benítez \& Soto, 2010; Gutiérrez \& Jiménez, 2013) and dead palms are a suitable nesting substrate for woodpeckers because the stem has lower values of hardness (Boyle, Ganong, Clark, \& Hast, 2008). Snags and posts abundance decreased in the semi-urban area, as well as their use by both woodpecker species. This is probably because snags and dead parts of live trees are considered dangerous for people due to the risk of collapsing and the consequential human or material damages (McClelland \& Frissell, 1975; DeLong et al., 2004; Blewett \& Marzluff, 2005). For this reason, snags and dead parts of live trees are usually removed from places with considerable urban development, consequently decreasing in the abundance of this type of nesting substrates for woodpeckers (Blewett \& Marzluff, 2005; Cockle et al., 2015). Changes in management by authorities in charge of utility posts could explain the decrease in posts suitable for woodpecker nesting by changing wood posts for concrete posts; however this is uncertain.

In spite of the similar amount of snags and posts in the urban zone over time, their use for nesting decreased. It is likely that their location in places with high vehicular traffic and human influence makes them a disadvantageous habitat for woodpecker nesting (Fornasari \& Kimberg, 2011), even when they could find potentially usable substrates for nesting. Pollution could be an agent which decreases habitat quality and influences other environmental factors, which could be important for nesting in both woodpecker species, such as the importance of food availability and acceptable levels of environmental noise (Fornasari \& Kimberg, 2011). Abundance of predators or nest robbers in the urban area such as cats (Dennis, 1969; Nilsson, 1984; Wilcove, 1985; Baker, Bentley, Ansell, \& Harris, 2005) may be another reason for the decrease in the use of substrates in the urban area.

The decline in cavity abundance between the two periods might be associated with differences in observers or survey accuracy between both periods, but we believe that this is not the case due to the following two reasons. First, the sampling was conducted by two observers (one expert and one with little experience) in 2005 and six observers (one expert and five with little experience) in 2015; if the number of observers increases the detectability of cavities, the expected pattern would be an increase in the cavity abundance, opposite to what we found. Second, in terms of survey accuracy we are confident that if bias occurred it was minimum, since the expert in both periods was the same; so he knew exactly which areas were sampled during 2005, therefore no differences in sample effort (more or less area sampled) were conducted in 2015. Furthermore, the same area size was sampled in both periods for the same amount of hours.

Biologically, the decline of cavity abundance may be caused for a reduction of the appropriate nesting substrate. For example not all the available substrates had the correctly hardness for nesting, a characteristic not measured in this study but very important for nest building in woodpeckers (Sandoval \& Barrantes, 2006; Sandoval, 2009). In addition, the observed decline may be caused for a reduction on the population of both woodpecker species between the study periods, but the lack of population studies in the area does not allow testing this hypothesis.

In conclusion, these types of studies that compare change of resources or species in the same area throughout time are very important in order to understand how human activities affect the resource availability for species (Magurran et al., 2010). In this investigation 
we showed that substrate abundance and use by two woodpecker species changed throughout time, especially in urban areas compared with semi-urban and non-urban areas. Given that this decrease in substrate abundance for nesting may limit woodpecker reproduction as well, it is important to take into account these types of substrates in conservation and management plans (Aitken, Wiebe, \& Martin, 2002; Cockle et al., 2015).

Ethical statement: authors declare that they all agree with this publication and made significant contributions; that there is no conflict of interest of any kind; and that we followed all pertinent ethical and legal procedures and requirements. All financial sources are fully and clearly stated in the acknowledgements section. A signed document has been filed in the journal archives.

\section{ACKNOWLEDGMENTS}

This project was conducted during the "Biología de Campo, 2015" University of Costa Rica's field course. We thank Juan Ignacio Abarca, Juan Carlos Azofeifa, Diego Solano and José Zelaya for their help during data collection and preliminary analysis as well as Luis Girón who provided help with the map. Anne Marie MacCaffrey kindly reviewed the English of the manuscript. LS thank Escuela de Biología for the half time designation. Finally we want to thank Jeffrey Sibaja and Daniel Rico who provided helpful comments during first versions of this manuscript and the anonymous reviewers whose comments improved the manuscript.

\section{RESUMEN}

Cambios en la abundancia de los sitios para anidar y su uso por carpinteros en un gradiente urbano: una comparación de diez años. La abundancia de sustratos para anidación de pájaras carpinteros puede reducirse debido a la expansión urbana, afectando negativamente su reproducción. Los estudios a largo plazo en los trópicos son escazos, pero valiosos para estimar cómo el desarrollo urbano ha afectado las comunidades ecológicas.
Presentamos una comparación de diez años sobre la abundancia y uso de sustratos de anidación de los carpinteros Melanerpes rubricapillus y M. chrysauchen en un gradiente urbano en Golfito, Costa Rica; que incluye tres hábitats y tres sustratos (tocones, palmas y postes). Las condiciones permanecieron similares en áreas no urbanas. En las áreas semi urbanas, los postes y tocones, así como los nidos en ellos disminuyeron. En áreas urbanas, a pesar de que los postes permanecieron constantes, su uso disminuyó. En las áreas semi urbanas y urbanas, la cantidad de palmas y de nidos en estas aumentó. Esta comparación a largo plazo indica que los carpinteros tomaron ventaja del aumento en la presencia de palmas ornamentales en los jardines.

Palabras clave: Costa Rica; Golfito; Melanerpes chrysauchen; Melanerpes rubricapillus; nidos; tocones.

\section{REFERENCES}

Aitken, K. E. H., Wiebe, K. L., \& Martin, K. (2002). Nestsite reuse patterns for a cavity-nesting bird community in interior British Columbia. Auk, 119, 391-402.

Baker, P. J., Bentley, A. J., Ansell, R. J., \& Harris, S. (2005). Impact of predation by domestic cats Felis catus in an urban area. Mammal Review, 35, 302-312.

Barrantes, G., \& Lobo, J. (2005). Protección de áreas silvestres en el bosque lluvioso del Pacífico húmedo de Costa Rica. In J. Lobo \& F. Bolaños (Eds.), Historia Natural de Golfito, Costa Rica (pp. 241-252). Heredia, Costa Rica: Inbio.

Benítez, B., \& Soto, F. (2010). El cultivo de la palma Areca (Dypsis lutescens, H. Wendel). Cultivos tropicales, $31,62-69$.

Blewett, C. M., \& Marzluff, J. M. (2005). Effects of urban sprawl on snags and the abundance and productivity of cavity-nesting birds. Condor, 107, 678-693.

Boyle, W. A., Ganong, C. N., Clark, D. B., \& Hast M. A. (2008). Density, distribution, and attributes of tree cavities in an old-growth tropical rain forest. Biotropica, 40, 241-245.

Cockle, K. L., Bodrati, A., Lammertink, M., \& Martin, K. (2015). Cavity characteristics, but not habitat, influence nest survival of cavity-nesting birds along a gradient of human impact in the subtropical Atlantic Forest. Biological Conservation, 184, 193-200.

Cornelius, C., Cockle, K., Politi, N., Berkunsky, I., Sandoval, L., Ojeda. V., ... \& Martin, K. (2008). Cavitynesting birds in neotropical forests: cavities as a potentially limiting resource. Ornitologia Neotropical, 19, 253-268.

DeLong, S. C., Fall, S. A., \& Sutherland, G. D. (2004). Estimating the impacts of harvest distribution on 
road-building and snag abundance. Canadian Journal of Forest Research, 34, 323-331.

Dennis, J. V. (1969). The yellow-shafted flicker (Colaptes auratus) on Nantucket Island, Massachusetts. Birdbanding, 40, 290-308.

Fornasari, L., \& Kimberg, P. (2011). UZGTL ESHSIAAvifauna specialist study assessment for ESHSIA. In Golder Associates Afrita (PTY) Ltd. (Eds.), Impact Assessment report for the Gas To Liquids project of OLTIN YO'L GTL, near Karshi, The Republic of Uzbekistan (Appendix K, pp. 1-130). Uzbekistan: Uzbekistan GTL LLC and Golder Associates for the Asian Development Bank. .

Garrigues, R., \& Dean, R. (2014). The birds of Costa Rica: a field guide (2 $2^{\text {nd }}$ ed.). New York: Cornell University Press.

Gibbs, J. P., Hunter, M. L., \& Melvin, S. M. (1993). Snag availability and communities of cavity nesting birds in tropical versus temperate forests. Biotropica, 25, 236-241.

Gorman, G. (2014). Woodpeckers of the world: the complete guide. London: A\&C Black.

Gutiérrez, M. V., \& Jiménez, K. (2013). Crecimiento de nueve especies de palmas ornamentales cultivadas bajo un gradiente de sombra. Agronomía Costarricense, 31, 9-19.

Lobo, J., \& Bolaños, F. (2005). Historia Natural de Golfito, Costa Rica. Heredia, Costa Rica: Inbio.

Magurran, A. E., Baillie, S. R., Buckland, S. T., Dick, J. M., Elston, D. A., Scott, E. M., ... Watt, A. D. (2010). Long-term datasets in biodiversity research and monitoring: assessing change in ecological communities through time. Trends in Ecology and Evolution, 25, 574-582.

McClelland, B. R., \& Frissell, S. S. (1975). Identifying forest snags useful for hole-nesting birds. Journal of Forestry, 73, 414-417.

Nilsson, S. G. (1984). The evolution of nest-site selection among hole-nesting birds: the importance of nest predation and competition. Ornis Scandinavica, 15, 167-175.

Peterson, A.W., \& Grubb Jr, T. C. (1983). Artificial trees as a cavity substrate for woodpeckers. Journal of Wildlife Management, 47, 790-798.

Remsen Jr., J. V., \& Robinson, S. K. (1990). A classification scheme for foraging behavior of birds in terrestrial habitats. Studies in Avian Biology, 13, 144-160.

Rico, D., \& Sandoval, L. (2014). Non-random orientation in woodpecker cavity entrances in a tropical rain forest. Ornitologia Neotroprical, 25, 237-243.

Rosero-Bixby, L., Maldonado-Ulloa, T., \& Bonilla-Carrión, R. (2002). Bosque y población en la Península de Osa, Costa Rica. Revista de Biología Tropical, 50, 585-598.

Sandoval, L. (2008). Implications of nest-site size selection on the nest building strategy in woodpeckers (Picidae: Aves). Métodos en Ecología \& Sistemática, $3,1-5$.

Sandoval, L. (2009). Densidad de sitios para anidar y su uso por dos especies de pájaro carpintero (Melanerpes rubricapillus y $M$. chrysauchen) (Piciformes: Picidae) en un gradiente urbano de Costa Rica. Revista de Biología Tropical, 57, 351-355.

Sandoval, L., \& Barrantes, G. (2006). Selección de árboles muertos por el Carpintero de Hoffmann (Melanerpes hoffmannii) para la construcción de nidos. Ornitología Neotropical, 17, 295-300.

Sandoval, L., \& Barrantes, G. (2009). Relationship between species richness of excavator birds and cavityadopters in seven tropical forests in Costa Rica. The Wilson Journal of Ornithology, 121, 75-81.

Short, L. L. (1979). Burdens of the picid hole-excavating habit. The Wilson Bulletin, 91, 16-28.

Stiles, F. G., \& Skutch, A. F. (1989). A guide to the birds of Costa Rica. Ithaca, NY: Comstock.

Wilcove, D. S. (1985). Nest predation in forest tracts and the decline of migratory songbirds. Ecology, 66, 1211-1214. 